María Nieves Tapia*

ORCID: 0000-0002-0403-9629

Buenos Aires, Argentyna

\title{
„Kochaj a zrozumiesz": charyzmat Chiary Lubich w dialogu z pedagogią uczenia się przez służbę (aprendizaje-servicio) ${ }^{1}$
}

\author{
"Love and You Will Understand": \\ Chiara Lubich's Charisma in Dialogue \\ with the Pedagogy of Service-Learning
}

Summary: Having originated from very old and diverse roots, the pedagogy of service-learning continues to spread on five continents under different names. It was given its present name in the USA and has developed systematically since 1968. Two years earlier, Chiara Lubich founded the Gen Movement, a youth-based branch of the Focolare Movement. The article explores her key speeches and messages that

* María Nieves Tapia jest absolwentką kierunku historia antycznego Rzymu, wykładała w Katedrze Historii Starożytnej na Papieskim Uniwersytecie Katolickim w Buenos Aires, od 1993 r. zajmuje się badaniem i promowaniem pedagogii uczenie się-służenie (aprendizaje-servicio), założyła i kieruje jej programami pod patronatem Ministerstwa Edukacji w Argentynie. Obecnie jest dyrektorką Centro Latinoamericano de Aprendizaje y Servicio Solidario - organizacji społecznej non profit, poświęconej promowaniu i badaniom dotyczącym aprendizaje-servicio (CLAYSS, www.clayss.org/info@clayss.org.ar). Adres: Yapeyú 283, C1202ACD Ciudad de Buenos Aires, Argentina; e-mail: info@clayss.org; ntapia@clayss.org.ar.

${ }^{1}$ Aprendizaje-servicio: dosłowne tłumaczenie to uczenie się przez służenie (aprendizaje „uczenie się”, servicio - „służenie”). 
she addressed to young people. Lubich's charisma inspired many practices and reflections on service-learning, laying the foundations for this pedagogy. They may be easier to understand if analysed through the prism of ideas discussed by Lubich in her studies, writings and works that inspired the Focolare Movement. The article presents the first reflections on the contemporary dialogue between Chiara Lubich's charisma and the pedagogy of service-learning. The first part proposes a brief introduction to the idea of pedagogy of service-learning, while the second offers an analysis of some of its fundamental features present in the dialogue with the "charisma of unity".

Keywords: service-learning; Chiara Lubich; pedagogy.

Streszczenie: Pedagogia uczenia się przez służbę (aprendizaje-servicio) rozprzestrzenia się na pięciu kontynentach pod różnymi nazwami, ma bardzo stare i różnorodne korzenie, lecz swoją nazwę zyskała w USA i zaczęła rozwijać się systematycznie od 1968 r. Dwa lata wcześniej Chiara Lubich założyła Ruch Gen, młodzieżowe odgałęzienie Ruchu Focolari. Główne przemówienia i przesłania, które kierowała do młodych, są podstawowym źródłem tego artykułu. Charyzmat Lubich zainspirował wiele praktyk i refleksji dotyczących uczenia się przez służbę oraz zasadnicze podstawy tej pedagogii. Mogą one stać się bardziej czytelne w zestawieniu z założeniami, które Lubich przedstawiła w swoich rozważaniach, pismach oraz twórczości inspirującej Ruch Focolari. Artykuł ukazuje pierwsze refleksje dotyczące współczesnego dialogu pomiędzy charyzmatem Chiary Lubich a pedagogią uczenia się przez służbę. W pierwszej części proponuje się krótkie wprowadzenie do idei pedagogii uczenia się przez służbę, w drugiej części dokonana została analiza niektórych jej fundamentalnych cech występujących w dialogu z ,charyzmatem jedności”.

Slowa kluczowe: uczenie się przez służbę; Lubich; pedagogia.

Celem tego artykułu jest ukazanie relacji występujących we współczesnym dialogu pomiędzy charyzmatem Chiary Lubich a pedagogią uczenia się przez służbę (aprendizaje-servicio) poprzez przedstawienie tego zagadnienia ze szczególnym uwzględnieniem literatury rozwiniętej w Ameryce Południowej i Hiszpanii. Pierwsza część artykułu zawiera krótkie wprowadzenie do założeń pedagogii uczenia się przez służbę, w drugiej części przyjrzymy się niektórym podstawom dialogu tej pedagogii z charyzmatem jedności. 


\section{Wprowadzenie do pedagogii uczenia się przez służbę}

Zbieranie ubrań i żywności dla poszkodowanych to pomoc.

Studiowanie architektury i projektowanie planów to nauka. Studiowanie architektury, projektowanie planów i przyczynianie się do budowy domów razem z potrzebujacymi to „uczenie się przez stużbę” (,, aprendizaje-servicio”).

Niemożliwe jest streszczenie obszernej literatury oraz współczesnych analiz dotyczących pedagogii znanej pod nazwą ,uczenie się przez zaangażowanie” (service-learning) lub ,uczenie się przez służbę" (aprendizaje-servicio) czy też omówienie jej wielowymiarowości w analizowanych aspektach kulturowych. W tytule paragrafu wprowadzającego wskazujemy, iż istnieje sporo możliwych definicji pojęcia uczenia się przez służbę: „uczyć się, służąc wspólnocie”, „refleksja i działanie na rzecz przemiany rzeczywistości”, „solidarne służenie młodych ludzi na podstawie zaplanowanych treści nauczania" .

Pierwsze przemiany pedagogiczne dotyczące tego zagadnienia mają ponad 50 lat i narodziły się pod wpływem myśli Johna Deweya i uczenia się przez doświadczenie (experiential learning) wraz z innymi nurtami pedagogicznymi drugiej połowy XX w., a w szczególności pedagogiki krytycznej Brazylijczyka Paula Freirego ${ }^{3}$.

Należy zaznaczyć, iż „historia teorii uczenia się przez służbę jest dużo starsza niż samo pojęcie" . Wiele instytucji edukacyjnych i organizacji społecznych na całym świecie rozwija projekty, w których uczenie się wyko-

${ }^{2}$ María Nieves Tapia, Aprendizaje y servicio solidario en el sistema educativo y las organizaciones juveniles (Buenos Aires: Ciudad Nueva, 2006).

3 Paulo Freire, Myles Horton, We Make the Road by Walking: Conversations on Education and Social Change (Philadelphia: Temple University Press, 1991); Thomas Deans, „Service-Learning in Two Keys: Paulo Freire's Critical Pedagogy in Relation to John Dewey's Pragmatism", Michigan Journal of Community Service Learning 6 (1999): 15-29; Danika M. Brown, Pulling it Together: A Method for Developing Service-Learning and Community Partnerships Based in Critical Pedagogy (Washington DC: National Service Fellow Research, 2001).

${ }^{4}$ Peter Titlebaum, Gabrielle Williamson, Corinne Daprano, Janine Baer, Jayne Brahler, Annotated History of Service Learning 1862-2002 (Dayton, OH: University of Dayton, May 2004). 
rzystywane jest dla zaoferowania realnej pomocy społeczeństwu, pomimo braku znajomości specjalistycznej terminologii i bibliografii o „uczeniu się przez służbę”. Zobaczmy kilka przykładów:

1. Dzieci z CEI Atalaya (Granada, Hiszpania) użyły swojej wiedzy z zakresu nauk przyrodniczych, aby zbadać, w jaki sposób można się przyczynić do poprawy stanu ekologicznego największego stawu w ich rodzinnym mieście Atarfe. Do tej inicjatywy włączyło się ponad 1000 mieszkańców. Dzięki ich akcji staw przeobraził się z powrotem w lustro krystalicznie czystej wody, w którym występują rodzime gatunki fauny i flory, stając się jednocześnie dużym ośrodkiem rekreacji i rozrywki dla całego miasta 5 .

2. W St. Mary County (Maryland, Stany Zjednoczone) uczniowie ósmych klas na zajęciach $\mathrm{z}$ historii badali proces przejścia $\mathrm{z}$ niewolnictwa do wyzwolenia w afroamerykańskim środowisku. W tym samym czasie rozwijali projekt utrzymania budynków starej plantacji niewolników Sotterley, która była lokalnym zagrożonym obiektem historycznym ${ }^{6}$.

3. Uczniowie ze szkół technicznych w argentyńskiej Patagonii wykorzystali swoją wiedzę, aby zaprojektować i zainstalować generatory wiatru oraz wody dla żyjącej na odludziu ludności wiejskiej

4. W Malezji studenci nauk ekonomicznych doradzali małym przedsiębiorstwom z peryferii Kuala Lumpur, jak zagwarantować firmie lepsze dochody, poprawiając funkcjonowanie księgowości, logistyki i marketingu ${ }^{8}$.

5. Grupa liderów francuskich przewodników uczestniczyła razem z harcerzami w projekcie animacyjnym dla dzieci i młodzieży uchodźczej z Afryki Subsaharyjskiej. Stosując to, czego nauczyli się w grupach, szkolili w zakresie pierwszej pomocy młodych uchodźców, aby ci mogli potem być animatorami w swoim środowisku i mogli uczyć dzieci uchodźców przez zabawę9.

5 Nagroda „Aprendizaje-servicio de España”, 2015, https://youtu.be/inkxzoeHK44, https://aprendizajeservicio.net/premio-aprendizaje-servicio-2015/. Oprócz adnotacji wszystkie linki były konsultowane w sierpniu $2018 \mathrm{r}$.

${ }^{6}$ Zob. www.nylc.org [dostęp: 7.10.2018].

7 Zob. https://youtu.be/8GLU1992gSY.

${ }^{8}$ UKM, National University of Malaysia, Strengthening Community Engagement. Nurturing Caring Citizens (Kuala Lumpur: UKM, 2012), 19.

9 Silvia Chanes, Graciana Gaona, María Nieves Tapia, „Caminos de solidaridad”, Con- 
Praktyka uczenia się przez służbę jest dziś rozwijana na pięciu kontynentach, na każdym poziomie edukacji formalnej, jak i edukacji nieformalnej, w organizacjach społecznych, szczególnie takich, gdzie pracuje się z dziećmi i młodzieżą. W innych kontekstach kulturowych praktyki uczenia się przez służbę można doszukiwać się w różnorodnościach genezy ${ }^{10}$, wpływów, wartości i wierzeń każdej kultury. Na przykład w języku chińskim używa się różnych znaków związanych z myśleniem Konfucjusza, aby objaśnić pojęcie uczenia się przez służbę ${ }^{11}$, w Indiach akademicka służba społeczna inspiruje się myślą Gandhiego ${ }^{12}$, w Ekwadorze kierunki promowania praktyki uczenia się przez służbę oparto na starodawnej tradycji keczua o ,idei dobrego życia"13.

Pedagogia uczenia się przez służbę jest odpowiedzią na cztery filary edukacji przewidzianej dla XXI w., które zostały przedstawione przez UNESCO: „uczyć się, aby wiedzieć; uczyć się, aby działać; uczyć się, aby być; uczyć się, aby żyć wspólnie" ${ }^{14}$, i jest bezpośrednio związana z większością nowych strategii pedagogicznych (uczenie się oparte na projektach, uczenie się oparte na problemach, uczenie się projektowania itp.). Jednocześnie stosuje ona strategie praktyki pedagogicznej i formy planowania charakterystyczne dla działalności wolontariatu i pracy socjalnej ${ }^{15}$.

Fakty wskazują, że dobre praktyki uczenia się przez służbę nie tylko wpływają na rozwiązywanie problemów społeczności, ale także bezpośrednio oddziałują na jakość uczenia się i integrację edukacyjną. Badania pro-

ferencia Internacional Católica del Guidismo, Documentos pedagógicos, 2006, http://www. clayss.org.ar/04_publicaciones/Caminosdesolidaridad-esp.pdf.

${ }^{10}$ PaSo Joven: Participación Solidaria para América Latina. „Manual de formación de formadores en aprendizaje-servicio y servicio juvenil" (Buenos Aires, BID-SES-CLAYSSALIANZA ONG-CEBOFIL, 2004), http://www.clayss.org.ar/paso_joven/index.htm.

${ }^{11}$ Office of Service-Learning, Lingnan University, Annual report 2011-2012 (Hong Kong: Lignan University, 2012).

${ }^{12}$ International Association for National Youth Service, Actas de la $6^{a}$ Conferencia Global/ Procedures of the VI Global Conference (Buenos Aires: CLAYSS, 2002).

${ }_{13}$ Aprendizaje-servicio (ApS): claves para su desarrollo en la Universidad, coord. Laura Rubio, Anna Escofet (Barcelona, Octaedro-ICE, 2017), 55-68.

${ }_{14}$ Jacques Delors, La educación encierra un tesoro (Buenos Aires: Santillana, Ediciones UNESCO, 1996); por. Jacques Delors, Edukacja - jest w niej ukryty skarb (Warszawa: Wyd. UNESCO, 1998).

15 Amanda Moore McBride, Carlos Benitez, Michael Sherraden, The forms and Nature of Civic Service: A Global Assessment (St Louis: Global Service Institute, Center for Social Development, Washington University in St. Louis, 2003). 
wadzone w różnych częściach świata ${ }^{16}$ pokazują pozytywny wpływ praktyki uczenia się przez służbę na jakość kompleksowego kształcenia; są to np. lepsze wyniki w nauce (nawet mierzone w standardowych testach), rozwój kompetencji w obszarze pracy, aktywność obywatelska, rozwój krytycznego myślenia, motywacja do badań, zachowania prospołeczne i inne. Potwierdzony został pozytywny wpływ dobrych praktyk uczenia się przez służbę na włączenie i utrzymanie w systemie edukacji grup społecznych najbardziej zagrożonych wykluczeniem. W związku z tym coraz większa liczba polityk edukacyjnych oraz instytucji na wszystkich poziomach na pięciu kontynentach zaczyna promować uczenie się przez służbę w celu przeprowadzenia reformy edukacji ${ }^{17}$.

16 Janet Eyler, Dwight E. Giles, Where's the learning in service-learning? (San Francisco: Jossey-Bass Publishers, 1999); Alba González, Pablo Elicegui, „El impacto de los proyectos de aprendizaje-servicio en la calidad educativa. Reflexiones en torno a ocho experiencias", w: Ministerio de Educación, Ciencia y Tecnología, Aprendizaje y servicio solidario. Actas del 5to. y 6to. Seminario Internacional „, Aprendizaje y servicio solidario” (República Argentina, 2004), 188-206; Shelley Billig, „Heads, Hearts, and Hands: The Research on K-12 Service Learning", w: Growing to Greatness: The State of Service Learning Project 2004 Report (St. Paul: NYLC \& State Farm, 2004); Shelley Billig, „Lessons from Reseach on Teaching and Learning: Service-learning as Effective Instruction”, w: Growing to Greatness: The State of Service Learning Project 2004 Report (St. Paul: NYLC \& State Farm, 2006); Andrew Furco, „Impacto de los proyectos de aprendizaje-servicio", w: Aprendizaje y servicio solidario en la Educación Superior y en los sistemas educativos latinoamericanos. Actas del 7mo. Seminario Internacional „Aprendizaje y Servicio Solidario” (República Argentina: Ministerio de Educación, 2005), 19-26, http://www.clayss.org.ar/seminario/anteriores/actas/2005_Actas7. pdf; Andrew Furco, ,The community as a resource for learning: an analysis of academic service-learning in primary and secondary education", w: The Nature of Learning. Using Research to Inspire Practice, red. Hanna Dumont, David Instance, Francisco Benavides (Paris: Organisation for Economic Co-operation and Development, Centre for Educational Research and Innovation, 2010); Barbara Jacoby, Service-learning Essentials. Questions, Answers, and Lessons Learned (San Francisco: Jossey Bass, 2015); CLAYSS, Programa de aprendizaje-servicio como política educativa nacional en Uruguay. Evaluación de resultados (Buenos Aires: CLAYSS-Porticus-Zigla, 2017).

${ }_{17}$ Roser Batlle, El aprendizaje-servicio en España: el contagio de una revolución pedagógica necesaria (Madrid: PPC, 2013); Rodrigo Mardones, Educación y fraternidad: Un principio para la formación ciudadana y la convivencia democrática (Buenos Aires: Ciudad Nueva, 2013); Enrique Ochoa, „Aprendizaje-servicio en América Latina. Apuntes sobre pasado y presente", TZHOECOEN 5 (2010): 108-125; María Nieves Tapia, Enrique Ochoa, „Legislación y normativa latinoamericana sobre servicio comunitario estudiantil y aprendizaje-servicio", w: Actas de la III Jornada de investigadores sobre aprendizaje-servicio, red. María Alejandra Herrero, María Nieves Tapia (Buenos Aires: CLAYSS-Red Iberoamericana de aprendizaje-servicio, 2015), 91-96. 


\section{Dialog między pedagogią uczenia się przez służbę a charyzmatem Chiary Lubich ${ }^{18}$}

W ciągu ostatnich 20 lat latynoamerykańscy naukowcy, którym bliska jest pedagogia uczenia się przez służbę podejmują dialog z charyzmatem ${ }^{19}$ Chiary Lubich, traktując go jako wkład w rozwój podstaw teoretycznych i metodologicznych pojęcia uczenia się przez solidarne służenie. Poniżej przedstawię najważniejsze wnioski wynikające z tego dialogu, a szczególnie odnoszące się do uczenia się przez służbę (aprendizaje-servicio solidario; AYSS), które koncentruje się wokół trzech głównych podstaw:

1. Działania solidarnego służenia mające na celu zaspokajanie w określony i skuteczny sposób rzeczywistych i odczuwanych potrzeb, realizowane razem ze społecznością, a nie tylko dla niej.

2. Aktywne zaangażowanie uczniów, od planowania do rezultatów.

18 Ta cześć łączy przemyślenia członków grupy CLAYSS, szczególnie osób ze stowarzyszenia CLAYSS zaangażowanych w Ruchu Focolari. Graciela del Campo, Protagonismo estudiantil solidario: alternativas de participación ciudadana y compromiso politico desde la escuela. La experiencia de estudiantes que participan de Proyectos educativos solidarios (Ponencia presentada en: Universidad Nacional de Avellaneda, Primeras Jornadas de Educación y Política, 24 de septiembre de 2013); Graciela del Campo, La educación solidaria en el marco de la nueva evangelización de lo social. Tesis de Maestría en Doctrina Social de la Iglesia (Madrid: Universidad Pontificia de Salamanca, inédito, 2015); Congregation for Catholic Education, Educating today and tomorrow. A renewing passion (Vatican City, 2014); Mardones, Educación; María Nieves Tapia, La solidaridad como pedagogía (Buenos Aires: Ciudad Nueva, 2000); Nieves Tapia, Aprendizaje; María Nieves Tapia, Gerardo Bridi, María Paula Maidana, Sergio Rial, El compromiso social como pedagogía. Aprendizaje y solidaridad en la escuela (Bogotá: CELAM, 2015). Zobacz też podręcznik do użytku wewnętrznego autorstwa Ruchu Gen Chicos por un Mundo Unido wydany przez Ruch Focolari: [Movimento dei Focolari, „Sei tappe per un obiettivo”, Teens (2018), http://www.teens4unity.org/wp-content/ uploads/2018-6x1-AgendaCs6_ITA-.pdf].

19 Celowo używamy terminu „charyzmat” - w ujęciu chrześcijańskim jest to dar ofiarowny przez Boga ludziom, aby korzystała z niego cała społeczność - a nie terminu, który występuje w środowisku akademickim, czyli „myśl” (hiszp. pensamiento). Uważam, że odpowiednie zrozumienie dziedzictwa Lubich wymaga analizy jej tekstów i zwyczajów jako osoby uczącej pokolenia młodych i dorosłych oraz nieodłącznej analizy relacji pomiędzy jej życiem a „charyzmatem jedności”, pomiędzy jej osobą a Ruchem Focolari, do którego skierowała słowa: „na nasz Ruch i na naszą historię można patrzeć jak na wielkie i niezwykłe wydarzenie wychowawcze” [Chiara Lubich, „Charyzmat jedności i pedagogika”, w: Chiara Lubich, Charyzmat jedności, red. Michele Vandeleene (Kraków: Fundacja Mariapoli i Wydawnictwo M, 2007), 313]. 
3. Zamierzone powiązanie $\mathrm{z}$ treścią nauczania (zawartą $\mathrm{w}$ programach nauczania, koncepcjach, w rozwoju kompetencji w zakresie działań obywatelskich i pracy oraz w badaniach) ${ }^{20}$.

\subsection{Solidarność braterska (relacja „horyzontalna”)}

Bez wątpienia jednym z najczęściej omawianych tematów na poziomie światowym powiązanych z uczeniem się przez służbę jest zakres i znaczenie terminu ,służenie”. Jak mówią eksperci południowoafrykańscy:

Musimy czynnie wybierać między uczeniem się przez służbę jako dobroczynnościąa a uczeniem się przez służbę jako przemianą społeczną [...]. Przemiana społeczna jest ściśle związana z programem sprawiedliwości społecznej mającym na celu pracę na rzecz społeczeństwa, w którym zarówno jednostki, jak i grupy mają dostęp do sprawiedliwego traktowania i dokładnie określonego udziału i w obowiązkach, i w korzyściach ${ }^{22}$.

W perspektywie CLAYSS ${ }^{23}$ i innych organizacji latynoamerykańskich ${ }^{24}$ wybór uczenia się przez służbę prowadzący do przemiany społecznej jest dokładnie wyrażony w koncepcji solidarnej służby i jej odmianach.

Zestawienie terminów „solidarny” i „służenie” ma na celu powiązanie praktyk uczenia się przez służbę z tworzeniem braterskich i solidarnych związków interpersonalnych, a także precyzyjne określenie terminu ,służenie", który w pewnych kontekstach może mieć negatywny wydźwięk, zarówno z punktu widzenia społecznego, jak i edukacyjnego. Jestem świadoma, że termin ,solidarność” nie ma identycznego znaczenia we wszystkich

${ }^{20}$ CLAYSS, Guía para desarrollar proyectos de aprendizaje-servicio solidario. Edición Perú (Lima: Ediciones CLAYSS, 2018), 30-39, http://www.clayss.org.ar/04_publicaciones/ Manual_Peru_para_web.pdf.

${ }^{21}$ W języku angielskim używa się terminu charity. W tym artykule wolałam użyć terminu, który opisuje to lepiej - beneficiencia („dobroczynność”). Dla chrześcijan Deus Caritas est rozumiane jest jako prawdziwa miłość czy chrześcijańskie miłosierdzie, które nie może być powiązywane tylko i wyłącznie z jałmużną czy dobroczynnością.

${ }^{22}$ Service-learning in South Africa, red. Ruksana Osman, Nadine Petersen (Cape Town: Oxford University Press, 2013), 9.

${ }^{23}$ Centro Latinoamericano de Aprendizaje y Servicio Solidario, www.clayss.org.

${ }^{24}$ Agrupadas en la Red Iberoamericana de aprendizaje-servicio, REDIBAS, http://www. clayss.org.ar/redibero.html. 
językach. Spróbuję zatem w poniższej tabeli krótko wyjaśnić zakres, w jakim go używam.

Tabela 1. Służenie pionowo, solidarność poziomo ${ }^{25}$

\begin{tabular}{|l|l|}
\hline \multicolumn{1}{|c|}{ Slużenie „wertykalnie” } & \multicolumn{1}{c|}{ Solidarność „horyzontalnie” } \\
\hline Dać - zrobić „dla” & $\begin{array}{l}\text { Udostępnić - zrobić „,z kimś”, wzajemność, } \\
\text { obopólność }\end{array}$ \\
\hline $\begin{array}{l}\text { Bezinteresowność egocentryczna: „sprawia, } \\
\text { że czuję się dobrze” }\end{array}$ & Empatia, związki prospołeczne \\
\hline Paternalizm & Braterskość \\
\hline Klientelizm & Empowerment (umożliwianie) \\
\hline $\begin{array}{l}\text { Przekazywanie wiedzy i wskazówek } \\
\text { z pozycji dominującej }\end{array}$ & Wymiana i wspólne gromadzenie wiedzy \\
\hline $\begin{array}{l}\text { Mimowolne tworzenie sytuacji } \\
\text { niesprawiedliwych oraz cyklów ubóstwa } \\
\text { i wykluczenia }\end{array}$ & $\begin{array}{l}\text { Znajomość praw, szukanie prawdy } \\
\text { i sprawiedliwości }\end{array}$ \\
\hline
\end{tabular}

\subsection{Miłość jako sens procesu uczenia się}

W tradycyjnym uczeniu się zdobywanie wiedzy jest zazwyczaj ukazane jako cel sam w sobie. Dla wielu uczniów sensem przejścia przez cykl edukacyjny jest tylko chęć uzyskania dyplomu, który przyczyni się do otrzymania lepszej pracy lub poprawienia sytuacji ekonomicznej ${ }^{26}$.

Koncepcja uczenia się przez służbę zawiera propozycję „uczenia się, aby móc służyć innym”. „Dla niektórych uniwersytetów celem istnienia jest doskonałość akademicka. Uważamy, że przyczyną naszego istnienia jest służenie innym, a doskonałość akademicka jest najlepszym narzędziem”"27.

${ }^{25}$ CLAYSS, Service-Learning in Central and Eastern Europe. Handbook for Engaged Teachers and Students (Buenos Aires: CLAYSS, 2017), 18-24, http://www.clayss.org.ar/04_ publicaciones/SL-EE nov17.pdf.

${ }^{26}$ Francisco, „Discurso a la comunidad de la Universidad Católica portuguesa con ocasión del 50 aniversario de su fundación", 26.10.2017, http://w2.vatican.va/content/francesco/es/speeches/2017/october/documents/papa-francesco_20171026_universita-cattolica-portoghese.html.

${ }_{27}$ Nauczyciele i studenci Wydziału Lekarskiego Uniwersytetu w Tucumán, Argentina, w: Ministerio de Educación, Ciencia y Tecnología, Experiencias ganadoras del Premio Pre- 
Jak wskazują Andrew Furco i inni ${ }^{28}$, tym, co motywuje uczniów oraz zachęca ich w większym stopniu do uczenia się w ramach tradycyjnych metod nauczania, jest humanitarny cel projektów uczenie się przez służbę. Ta propozycja świadomej edukacji stanowi również główne przesłanie Chiary Lubich do młodych z Ruchu Focolari - Ruchu Gen. W jednym z pierwszych przesłań powiedziała: „Jeśli lekceważysz twoje uczenie się, to jesteś nieodpowiedzialny. Jeśli uczysz się dla ocen, jesteś dumny. Jeśli uczysz się z miłości do Boga i innych, to odnalazłeś harmonię"29.

W pierwszych latach działalności Ruchu Gen stworzono frazę, w której zawarto ścisły związek między realną miłością do bliźniego a światłem największego zrozumienia duchowego i ludzkiego: „kochaj, a zrozumiesz”. Jest to stwierdzenie, które mogłoby być uważane za odpowiednie wyłącznie dla życia duchowego, jednakże z punktu widzenia edukacyjnego jest ono również właściwe, by wdrażać uczenie się przez służbę. Za sprawą realizowania projektów solidarności ze wspólnotą uczniowie mogą stosować oraz rozwijać wiedzę i kompetencje, wykorzystywać swoje zdolności, wzmacniać postawy prospołeczne i pogłębiać obywatelskie zaangażowanie ${ }^{30}$.

Chiara Lubich doceniała znaczenie praktyki solidarności w procesie formacji młodzieży. W przesłaniu z 1977 r. do młodych zaangażowanych w Ruchu Gen powiedziała:

Zrozumieliście duchowość, ale tym, którzy dopiero weszli do Ruchu, wyjaśniam, że nie możecie zadowolić się tylko życiem 24 godziny na dobę w wymiarze duchowym. Konieczne jest także ofiarować się [...] biednym i chorym. Należy poświęcić się temu zadaniu natychmiast, kochając odnajdziecie światło i ze światłem, którym jest Bóg, pokochacie jeszcze bardziej. Dlatego hasłem jest: oddać swoje życie dla innych ludzi ${ }^{31}$.

Faktycznie, ważną częścią działań formacyjnych prowadzonych przez Lubich wobec młodych z Ruchu było częste organizowanie międzynarodo-

sidencial „Prácticas Solidarias en Educación Superior” 2004 (República Argentina: MECyT, 2006), 11.

${ }^{28}$ Furco, „Impacto”.

29 Chiara Lubich, 100 Pensamientos (Buenos Aires: Ciudad Nueva, 1989), 16.

${ }^{30}$ Eyler, Giles, Where's the learning; Billig, „Heads”; Billig, „Lessons”; Jacoby, Service-learning.

${ }^{31}$ Chiara Lubich, Coloquios con los Gen desde 1966 hasta 2000 (Buenos Aires: Ciudad Nueva, 2005), 348. 
wych akcji solidarności, jak np. Operacja Afryka ${ }^{32}$, mających na celu rozwój lokalnych dzieł społecznych.

Prawdziwa miłość, „Nowe przykazanie” oddania życia za braci, jest w samym centrum chrześcijańskiego przekazu i charyzmatu jedności.

W swojej pierwszej książce pt. Rozważania Lubich stwierdza, że jeśli jako uczniowie znalibyśmy pytania, które otrzymamy na egzaminie końcowym, uznalibyśmy to za szczęście i sumiennie przygotowalibyśmy się do odpowiedzi na nie. Przypomina nam, że Mistrz już zostawił pytania, na które przyjdzie nam odpowiedzieć u kresu życia:

Życie jest próbą i z niego również na końcu trzeba zdać egzamin, a nieskończona miłość Boga podpowiedziała już człowiekowi, jakie będą pytania: „Byłem głodny, a daliście mi jeść; byłem spragniony, a daliście mi pić" (Mt 25,35). Przedmiotem tego egzaminu będą uczynki miłosierdzia, te uczynki, dzięki którym Bóg widzi, czy naprawdę kochaliśmy go, służąc mu w bliźnim ${ }^{33}$.

Można by z tego wysunąć wniosek, że z chrześcijańskiej perspektywy uczenie się przez służbę jest uczeniem się, które pozwala przygotować się do „końcowego egzaminu”.

Według innych religii oznaczałoby to uczyć się żyć według „,złotej zasady"34, czyli czynienia bliźniemu tego, co chcielibyśmy, żeby nam czyniono ${ }^{35}$. Z perspektywy niereligijnej można by powiedzieć, że najważniejszym wyzwaniem dla istoty ludzkiej jest zdolność do świadomego kochania innych, uczenia się tego, co Erich Fromm nazywał ,sztuką miłości”36. W takim ujęciu uczenie się przez służbę można by uznać za rodzaj dydaktyki dotyczącej uczenia się, jak kochać, a w szczególności jak kochać innych.

Istotą nauczania Chiary Lubich jest „,sztuka miłości” ${ }^{37}$. Lubich podsumowała to w sześciu głównych zasadach, które mogą stanowić solidną pod-

32 Por. http://www.focolare.org/news/2009/01/10/per-colmare-un-debito-nasce-1\%e2\% 80\%99operazione-africa/.

${ }^{33}$ Chiara Lubich, „Egzamin” w: Lubich, Charyzmat, 126-127.

${ }^{34}$ Bill Puka, „The Golden Rule”, w: The Internet Encyclopedia of Philosophy, red. James Fieser, Bradley Dowden, http://www.iep.utm.edu/goldrule/; por. La regola d'oro come etica universale, red. Carmelo Vigna, Susy Zandaro (Milano: Vita e Pensiero, 2005).

${ }^{35}$ Chiara Lubich, „Discurso a los jóvenes reunidos delante del Coliseo de Roma para el Supercongreso Gen", Roma, 26.05.2002, http://www.focolare.org/es/news/2016/01/03/ la-regola-doro-come-via-per-la-costruzione-della-fratellanza-e-della-pace/.

${ }^{36}$ Erich Fromm, O sztuce miłości (Poznań: Rebis, 2000).

37 Chiara Lubich, El Arte de amar (Buenos Aires: Ciudad Nueva, 2007). 
stawę refleksji nad różnymi rodzajami związków interpersonalnych i społecznych zachodzących $\mathrm{w}$ projektach uczenia się - solidarnego służenia

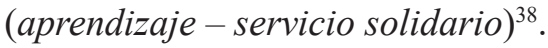

Chociaż temat bez wątpienia zasługuje na głębszą analizę, to jej dokonanie w ramach niniejszego artykułu nie jest możliwe. W podanej poniżej tabeli przedstawione zostały najistotniejsze elementy poruszanego problemu.

Tabela 2. Sześć zasad sztuki miłości

\begin{tabular}{|c|c|}
\hline Sztuka milościa) & $\begin{array}{c}\text { Uczenie się - solidarne służenie } \\
\text { Aprendizaje - servicio solidario (AYSS) }\end{array}$ \\
\hline $\begin{array}{l}\text { 1. „Kochać wszystkich”: oznacza żyć } \\
\text { bratersko i być gotowym służyć innym } \\
\text { (Łk 22,27). }\end{array}$ & $\begin{array}{l}\text { Praktyki AYSS przyczyniają się do } \\
\text { usunięcia siebie z centrum (decentralizacji) } \\
\text { oraz otwierania instytucji edukacyjnych na } \\
\text { danym obszarze w celu wyjścia naprzeciw } \\
\text { problemom, które dotykają całej grupy } \\
\text { społecznejb) }\end{array}$ \\
\hline $\begin{array}{l}\text { 2. „Kochać jako pierwszy”: to } \\
\text { podejmowanie inicjatyw jak Maryja, } \\
\text { która „udała się z pośpiechem”, aby } \\
\text { zająć się swoją kuzynką Elżbietą } \\
\text { (Łk 1,39): nieodpłatnie, bez } \\
\text { oczekiwania na rekompensatę. }\end{array}$ & $\begin{array}{l}\text { Jedną z najistotniejszych kwestii } \\
\text { poruszanych przez tę pedagogię jest } \\
\text { prowadzenie młodych i motywowanie } \\
\text { ich do udziału w planowaniu } \\
\text { i konkretyzowaniu projektów } \\
\text { solidarnościowych }{ }^{c} \text {. }\end{array}$ \\
\hline $\begin{array}{l}\text { 3. „Kochać jak siebie samego": czyli } \\
\text { "Czynić innym to, co chcemy, żeby } \\
\text { ludzie nam czynili” ( } \operatorname{l} \text { k 7,31). }\end{array}$ & $\begin{array}{l}\text { Dobre praktyki AYSS przyczyniają się do } \\
\text { kształtowania postaw prospołecznych }{ }^{\mathrm{d}} \text {, } \\
\text { pokonywania egocentrycznych postaw oraz } \\
\text { braku zainteresowania dobrem wspólnym, } \\
\text { a także środowiskiem społecznym, które to } \\
\text { postawy czasami występują w instytucjach } \\
\text { edukacyjnych. }\end{array}$ \\
\hline $\begin{array}{l}\text { 4. „Jednoczyć się": jak wyjaśnia to } \\
\text { św. Paweł, ,stałem się wszystkim dla } \\
\text { wszystkich” (1 Kor 9,22). Oznacza to } \\
\text { kochać i traktować jak swoje potrzeby } \\
\text { oraz oczekiwania innych. }\end{array}$ & $\begin{array}{l}\text { Pedagogika AYSS popiera rozwój } \\
\text { empatiie), kładzie nacisk na określanie } \\
\text { celów projektów poprzez ich } \\
\text { odpowiednią diagnozę, właściwe } \\
\text { słuchanie oraz wzajemną empatię } \\
\text { między podmiotami, zarówno na } \\
\text { poziomie relacji międzyludzkich, jak } \\
\text { i międzyinstytucjonalnych }{ }^{\mathrm{f}} \text {. }\end{array}$ \\
\hline
\end{tabular}

${ }^{38}$ Del Campo, La educación. 
Tabela 2. Sześć zasad sztuki miłości

\begin{tabular}{|c|c|}
\hline Sztuka miłościa) & $\begin{array}{c}\text { Uczenie się - solidarne służenie } \\
\text { Aprendizaje - servicio solidario (AYSS) }\end{array}$ \\
\hline $\begin{array}{l}\text { 5. „Kochać Jezusa w każdym”: czyli } \\
\text { „Wszystko, co uczyniliście jednemu } \\
\text { z tych braci moich najmniejszych, } \\
\text { Mnieście uczynili” (Mt 25,40). }\end{array}$ & $\begin{array}{l}\text { Chociaż pedagogia AYSS jest uznawana } \\
\text { w świeckich środowiskach edukacyjnych } \\
\text { i przez różne koncepcje filozoficzne } \\
\text { oraz religijne, to w kontekście edukacji } \\
\text { chrześcijańskiej solidarnościowe praktyki } \\
\text { edukacyjne pozwalają przemyśleć } \\
\text { i intensywnie dostrzegać obecność Jezusa } \\
\text { w każdym członku wspólnoty oraz } \\
\text { uczyć się istoty miłości do bliźniego za } \\
\text { sprawą czynów i prawdy }(1 \mathrm{~J} 3,18)^{\mathrm{g}} \text {. }\end{array}$ \\
\hline $\begin{array}{l}\text { 6. „Miłość wzajemna”: zgodnie } \\
\text { z nauczaniem Jezusa oznacza: } \\
\text { „Abyście się wzajemnie miłowali, tak } \\
\text { jak ja was umiłowałem” (J 15,12-13). } \\
\text { A „Gdy ktoś życie swoje oddaje za } \\
\text { przyjaciół swoich” (J 15,12-13), } \\
\text { to prędzej czy później tworzy } \\
\text { wzajemność i miłość wzajemną } \\
\text { oraz potwierdza obecność Jezusa } \\
\text { we wspólnocie zjednoczonej w jego } \\
\text { Imię (Mt 18,20). Jezus obecny } \\
\text { pośród tych, którzy się kochają, może } \\
\text { wypełnić swój „testament” z ostatniej } \\
\text { wieczerzy: ,aby wszyscy stanowili } \\
\text { jedno, jak Ty, Ojcze, we Mnie, a Ja } \\
\text { w Tobie, aby i oni stanowili w Nas } \\
\text { jedno”. }\end{array}$ & $\begin{array}{l}\text { AYSS buduje postawę wspólnego } \\
\text { uczenia się nie tylko między uczniami, } \\
\text { lecz także między instytucjami } \\
\text { edukacyjnymi i wspólnymi podmiotami. } \\
\text { Proponuje ,solidarność horyzontalną”h) } \\
\text { i zdobywanie wiedzy jako wzajemny dar, } \\
\text { w którym uczenie się staje się prawdziwie } \\
\text { akademickie, jeśli jest wzmacniane przez } \\
\text { umiejętności nabyte w praktyce oraz pełen } \\
\text { szacunku dialog z lokalną i tradycyjną } \\
\text { kulturą, połączony łańcuchem „obopólnych } \\
\text { korzyści”. } \\
\text { W kontekście edukacji chrześcijańskiej } \\
\text { AYSS pozwala tworzyć więzi pomiędzy } \\
\text { nauczycielami, uczniami i innymi } \\
\text { członkami wspólnoty. Gotowi do ,oddania } \\
\text { życia dla innych ludzi” poprzez konkretne } \\
\text { działanie tam, gdzie są, na rzecz innych, } \\
\text { dają świadectwo, tworząc „fragmenty } \\
\text { braterstwa”. }\end{array}$ \\
\hline
\end{tabular}

a) Chiara Lubich, El Arte de amar (Buenos Aires: Ciudad Nueva, 2007).

b) CLAYSS, Escuelas para el encuentro. Cómo desarrollar un proyecto de aprendizaje-servicio (Buenos Aires: CLAYSS, 2017), 47; http://www.clayss.org.ar/ 04 publicaciones/Manual_CLAYSS_Scholas.pdf.

c) Graciela del Campo, Protagonismo estudiantil solidario: alternativas de participación ciudadana y compromiso político desde la escuela. La experiencia de estudiantes que participan de Proyectos educativos solidarios (Ponencia 
presentada en: Universidad Nacional de Avellaneda, Primeras Jornadas de Educación y Política, 24 de septiembre de 2013)

d) Donald Eberly, Roberto Roche Olivar, „Aprendizaje-servicio y prosocialidad”, w: CLAYSS, Aprender sirve, servir enseña (Buenos Aires: CLAYSS, 2002), 33-48.

e) Laura Campo, „El aprendizaje servicio en la universidad como propuesta pedagógica”, w: Aprendizaje servicio y responsabilidad social de las universidades, red. Miquel Martínez Martín (Barcelona: Octaedro, 2008), 81-91; Roser Batlle, „Aprendizaje Servicio para una Educación Empática”, https://youtu.be/ ZLFbydlaC0E.

f) María Nieves Tapia, Gerardo Bridi, María Paula Maidana, Sergio Rial, El compromiso social como pedagogía. Aprendizaje y solidaridad en la escuela (Bogotá: CELAM, 2015), 73-81.

g) Francisco, „Mensaje I Jornada Mundial de los Pobres”, 19.11.2017, https://w2. vatican.va/content/francesco/es/messages/poveri/documents/papa-francesco 20170613 messaggio-i-giornatamondiale-poveri-2017.html.

h) Antonio Maria Baggio, „Se la politica riscopre la fraternità”, Avvenire (Roma, 05.04.2007).

\subsection{Miłość, która tworzy i przemienia społeczność}

W jednym ze swoich przekazów do młodych członków Ruchu Chiara Lubich powiedziała, że konieczne jest ,podejmowanie działań” w ich miastach w celu przeprowadzenia zmian, a jeśli kocha się Boga, ,Jedno miasto to za mało" 39 . Analiza tego tekstu z perspektywy AYSS zasługuje jednak na oddzielny artykuł. Wystarczy wskazać, że narzędzia metodologiczne opracowane dzięki uczeniu się przez służbę, takie jak planowanie projektów ${ }^{40}$, zakładają - podobnie jak Lubich - że już od dziecka ,wszyscy jesteśmy kandydatami" do zmieniania świata. Aby to czynić, nie wystarczą tylko dobre chęci, lecz potrzeba mądrej miłości, która będzie wskazywać, planować i osiągać wyznaczone cele.

39 Chiara Lubich, „Jedno miasto to za mało”, w: Lubich, Charyzmat, 160-164.

40 CLAYSS, Escuelas, 56-86; Ministerio de Educación, Itinerario y herramientas para desarrollar un proyecto de aprendizaje-servicio (Buenos Aires: Ministerio de Educación de la Nación, 2015) https://www.argentina.gob.ar/sites/default/files/edusol-itinerario-y-herramientas-edicion-2014-5901e6a68e7dd.pdf. 
$\mathrm{Z}$ tego punktu widzenia pedagogia AYSS to ogromne narzędzie, które jest już używane przez tysiące instytucji edukacyjno-religijnych, aby łączyć w tym samym projekcie wiedzę akademicką, rozwój kompetencji oraz formację ludzką i religijną ${ }^{41}$. W myśl słów papieża Franciszka pedagogia AYSS pozwala jednoczyć ,język głowy, serca i rąk"42.

\section{Wnioski}

Ze względu na ograniczoną objętość tego artykułu nie jest możliwe rozwinięcie innych zagadnień dotyczących teoretycznych podstaw, omówienie pozostałych narzędzi i metodologii typowych dla pedagogii uczenia się przez służbę czy też ukazanie innych jej powiązań z charyzmatem Chiary Lubich. Sądzę, że przedstawione elementy pokazują już wystarczającą liczbę punktów wspólnych.

Chociaż wpływ myśli Lubich na pedagogię uczenia się przez służbę jest stosunkowo świeży i opisany niemalże wyłącznie w literaturze hiszpańskiej oraz włoskiej, moim zdaniem podobieństwo między charyzmatem Chiary Lubich i uczeniem się przez służbę otwiera nowe możliwości do dalszych badań z tym związanych.

Papież Franciszek podkreśla, że „nie zmienimy świata, jeśli nie zmienimy edukacji”" ${ }^{33}$. Jestem przekonana, że praktyki, które wiążą się z uczeniem się i służeniem innym, pozwolą realizować się tym dwóm celom jednocześnie. Mam nadzieję, że ten krótki artykuł zachęci do rozwijania projektów według koncepcji uczenia się przez służbę w Polsce, jak i w innych częściach świata.

Ttumaczenie: Magdalena Mtynek Konsultacje: Mariola T. Kozubek

${ }^{41}$ Tapia, Bridi, Maidana, Rial, El compromiso; Arantzazu Martinez-Odria, Isabel Gómez Villalba, Aprendizaje-servicio (educar para el encuentro (Madrid, Editorial KHAK, 2018).

42 Francisco, „Discorso ai partecipanti al Congresso Mondiale promosso dalla Congregazione per l'Educazione Cattolica”, 21.10.2015, http://w2.vatican.va/content/francesco/it/ speeches/2015/november/documents/papa-francesco_20151121_congresso-educazione-cattolica.html.

${ }^{43}$ Francisco, ,Mensaje al Congreso de Scholas”, 5.02.2015, http://w2.vatican.va/content/ francesco/es/speeches/2015/february/documents/papa-francesco_20150205_scholas-occurrentes.html. 


\section{Bibliografia}

Baggio, Antonio Maria. „Se la politica riscopre la fraternità”. Avvenire, Roma, 05.04. 2007.

Batlle, Roser. „Aprendizaje Servicio para una Educación Empática”. https://youtu. be/ZLFbydlaC0E.

Batlle, Roser. El aprendizaje-servicio en España: el contagio de una revolución pedagógica necesaria. Madrid: PPC, 2013.

Billig, Shelley. „Lessons from Reseach on Teaching and Learning: Service-learning as Effective Instruction". W: Growing to Greatness: The State of Service Learning Project 2004 Report. St. Paul: NYLC \& State Farm, 2006.

Billig, Shelley. „Heads, Hearts, and Hands: The Research on K-12 Service Learning”. W: Growing to Greatness: The State of Service Learning Project 2004 Report. St. Paul: NYLC \& State Farm, 2004.

Brown, Danika M. Pulling it Together: A Method for Developing Service-Learning and Community Partnerships Based in Critical Pedagogy. Washington DC: National Service Fellow Research, 2001.

Campo, Laura. „El aprendizaje servicio en la universidad como propuesta pedagógica". W: Aprendizaje servicio y responsabilidad social de las universidades, red. Miquel Martínez Martín, 81-91. Barcelona: Octaedro, 2008.

Chanes, Silvia, Graciana Gaona, María Nieves Tapia. „Caminos de solidaridad”. Conferencia Internacional Católica del Guidismo. Documentos pedagógicos. 2006. http://www.clayss.org.ar/04_publicaciones/Caminosdesolidaridad-esp.pdf.

CLAYSS (Centro Latinoamericano de Aprendizaje y Servicio Solidario-Scholas). Escuelas para el encuentro. Cómo desarrollar un proyecto de aprendizaje-servicio. Buenos Aires: CLAYSS, 2017. http://www.clayss.org.ar/04_publicaciones/Manual_CLAYSS_Scholas.pdf.

CLAYSS. Guía para desarrollar proyectos de aprendizaje-servicio solidario. Edición Perú. Lima: CLAYSS, 2018. http://www.clayss.org.ar/04_publicaciones/ Manual_Peru_para_web.pdf.

CLAYSS. Programa de aprendizaje-servicio como política educativa nacional en Uruguay. Evaluación de resultados. Buenos Aires: CLAYSS-Porticus-Zigla, 2017.

CLAYSS. Service-Learning in Central and Eastern Europe. Handbook for Engaged Teachers and Students. Buenos Aires: CLAYSS, 2017. http://www.clayss.org. ar/04_publicaciones/SL-EE_nov17.pdf.

Congregation for Catholic Education. Educating today and tomorrow. A renewing passion. Vatcan City, 2014. 
Deans, Thomas. „Service-Learning in Two Keys: Paulo Freire’s Critical Pedagogy in Relation to John Dewey's Pragmatism". Michigan Journal of Community Service Learning 6 (1999): 15-29.

Del Campo, Graciela. La educación solidaria en el marco de la nueva evangelización de lo social. Tesis de Maestría en Doctrina Social de la Iglesia. Madrid: Universidad Pontificia de Salamanca, 2015. Texto inédito.

Del Campo, Graciela. Protagonismo estudiantil solidario: alternativas de participación ciudadana y compromiso político desde la escuela. La experiencia de estudiantes que participan de Proyectos educativos solidarios. Ponencia presentada en: Universidad Nacional de Avellaneda, Primeras Jornadas de Educación y Política, 24 de septiembre de 2013.

Delors, Jacques. La educación encierra un tesoro. Buenos Aires: Santillana, Ediciones UNESCO, 1996.

Eberly, Donald J. National Service: A Promise to Keep. Rochester, NY: John Alden Books, 1988.

Eberly, Donald, Roberto Roche Olivar. „Aprendizaje-servicio y prosocialidad”. W: CLAYSS, Aprender sirve, servir enseña, 33-48. Buenos Aires: CLAYSS, 2002.

Eyler, Janet, Dwight E. Giles. Where's the learning in service-learning? San Francisco: Jossey-Bass Publishers, 1999.

Francisco. „Discorso ai partecipanti al Congresso Mondiale promosso dalla Congregazione per l'Educazione Cattolica", 21.10.2015. http://w2.vatican.va/content/ francesco/it/speeches/2015/november/documents/papa-francesco_20151121_ congresso-educazione-cattolica.html.

Francisco. „Discurso a la comunidad de la Universidad Católica portuguesa con ocasión del 50 aniversario de su fundación", 26.10.2017. http://w2.vatican.va/ content/francesco/es/speeches/2017/october/documents/papa-francesco_20 171026_universita-cattolica-portoghese.html.

Francisco. „Mensaje al Congreso de Scholas”, 5.02.2015. http://w2.vatican.va/content/francesco/es/speeches/2015/february/documents/papa-francesco_2015 0205 scholas-occurrentes.html.

Francisco. „Mensaje I Jornada Mundial de los Pobres”, 19.10.2017. https://w2.vatican.va/content/francesco/es/messages/poveri/documents/papa-francesco_20 170613_messaggio-i-giornatamondiale-poveri-2017.html.

Freire, Paulo, Myles Horton. We Make the Road by Walking: Conversations on Education and Social Change. Philadelphia: Temple University Press, 1991.

Fromm, Erich. O sztuce miłości. Poznań: Rebis, 2000.

Furco, Andrew. „Impacto de los proyectos de aprendizaje-servicio”. W: Aprendizaje y servicio solidario en la Educación Superior y en los sistemas educativos latinoamericanos. Actas del 7mo. Seminario Internacional „, Aprendizaje y Ser- 
vicio Solidario", 19-26. República Argentina: Ministerio de Educación, 2005. http://www.clayss.org.ar/seminario/anteriores/actas/2005_Actas7.pdf.

Furco, Andrew. „The community as a resource for learning: an analysis of academic service-learning in primary and secondary education". W: The Nature of Learning. Using Research to Inspire Practice, red. Hanna Dumont, David Instance, Francisco Benavides. Paris: Organisation for Economic Co-operation and Development, Centre for Educational Research and Innovation, 2010.

González, Alba, Pablo Elicegui. „El impacto de los proyectos de aprendizaje-servicio en la calidad educativa. Reflexiones en torno a ocho experiencias". W: Ministerio de Educación, Ciencia y Tecnología, Aprendizaje y servicio solidario. Actas del 5to. y 6to. Seminario Internacional "Aprendizaje y servicio solidario", 188-206. República Argentina, 2004.

International Association for National Youth Service. Actas de la $6^{a}$ Conferencia Global/Procedures of the VI Global Conference. Buenos Aires: CLAYSS, 2002. Jacoby, Barbara. Service-learning Essentials. Questions, Answers, and Lessons Learned. San Francisco: Jossey Bass, 2015.

La regola d'oro come etica universale, red. Carmelo Vigna, Susy Zandaro. Milano: Vita e Pensiero, 2005.

Lubich, Chiara. „Discurso a los jóvenes en Loppiano”, FI, Italia, 2.05.2006. http:// www.focolare.org/es/news/2006/05/02/una-citta-non-basta/.

Lubich, Chiara. „Discurso a los jóvenes reunidos delante del Coliseo de Roma para el Supercongreso Gen", Roma, 26.05.2002. http://www.focolare.org/es/ news/2016/01/03/la-regola-doro-come-via-per-la-costruzione-della-fratellanza-e-della-pace/.

Lubich, Chiara. 100 Pensamientos. Buenos Aires: Ciudad Nueva, 1989.

Lubich, Chiara. Charyzmat jedności, red. Michele Vandeleene. Kraków: Fundacja Maripoli, Wydawnictwo M, 2007.

Lubich, Chiara. Coloquios con los Gen desde 1966 hasta 2000. Buenos Aires: Ciudad Nueva, 2005.

Lubich, Chiara. El Arte de amar. Buenos Aires: Ciudad Nueva, 2007.

Lubich, Chiara. Meditaciones. Buenos Aires: Ciudad Nueva, 1971.

Lubich, Chiara. Mensaje a los jóvenes. Roma, 2006.

Lubich, Chiara. Scritti Spirituali (I). Roma: Città Nuova, 1978.

Lubich, Chiara. Una cultura nueva para una nueva sociedad. Doctorados honoris causa-Congresos Internacionales (1996-2001). Buenos Aires: Ciudad Nueva, 2003.

Mardones, Rodrigo. Educación y fraternidad: Un principio para la formación ciudadana y la convivencia democrática. Buenos Aires: Ciudad Nueva, 2013. 
Martín García, Xus. Per a una pedagogía del servei. Treball per projectes i APS. Barcelona: Minyons Escoltes Guies Sant Jordi de Catalunya, 2012.

Martinez-Odria, Arantzazu, Isabel Gómez Villalba. Aprendizaje-servicio (educar para el encuentro). Madrid: Editorial KHAK, 2018.

Ministerio de Educación, Ciencia y Tecnología. Experiencias ganadoras del Premio Presidencial „Prácticas Solidarias en Educación Superior” 2004. República Argentina: MECyT, 2006.

Ministerio de Educación. Experiencias ganadoras del Premio Presidencial „Escuelas Solidarias” 2009. República Argentina: Ministerio de Educación, 2010.

Moore McBride, Amanda, Carlos Benitez, Michael Sherraden, Danso Kwofie, Beatriz Castaño, Lissa Johnson, Maury Mendenhall, Erica Sulever, Erdenechimeg Tserendorj, Jenny Brav, Lacey Clark. The forms and Nature of Civic Service: A Global Assessment. Washington: University in St. Louis, Global Service Institute, Center for Social Development, 2003.

Movimento dei Focolari. „Sei tappe per un obietivo”. Teens (2018).

Ochoa, Enrique. „Aprendizaje-servicio en América Latina. Apuntes sobre pasado y presente". TZHOECOEN 5 (2010): 108-125.

Office of Service-Learning, Lingnan University. Annual report 2011-2012. Hong Kong: Lignan University, 2012.

PaSo Joven: Participación Solidaria para América Latina. „Manual de formación de formadores en aprendizaje-servicio y servicio juvenil". Buenos Aires: BID-SESCLAYSS-ALIANZA ONG-CEBOFIL, 2004. http://www.clayss.org.ar/paso_ joven/index.htm

Puka, Bill. „The Golden Rule”. W: The Internet Encyclopedia of Philosophy, red. James Fieser, Bradley Dowden. http://www.iep.utm.edu/goldrule/.

Service-learning in South Africa, red. Ruksana Osman, Nadine Petersen. Cape Town: Oxford University Press, 2013.

Tapia, María Nieves, Enrique Ochoa. „Legislación y normativa latinoamericana sobre servicio comunitario estudiantil y aprendizaje-servicio". W: Actas de la III Jornada de investigadores sobre aprendizaje-servicio, red. María Alejandra Herrero, María Nieves Tapia, 91-96. Buenos Aires: CLAYSS-Red Iberoamericana de aprendizaje-servicio, 2015.

Tapia, María Nieves, Gerardo Bridi, María Paula Maidana, Sergio Rial. El compromiso social como pedagogía. Aprendizaje y solidaridad en la escuela. Bogotá: CELAM, 2015.

Tapia, María Nieves. „Aprendizaje-servicio, un movimiento pedagógico mundial”. W: Aprendizaje-servicio (ApS): claves para su desarrollo en la Universidad, red. Laura Rubio, Anna Escofet, 55-68. Barcelona: Octaedro-ICE, 2017. 
Tapia, María Nieves. Aprendizaje y servicio solidario en el sistema educativo y las organizaciones juveniles. Buenos Aires: Ciudad Nueva, 2006.

Tapia, María Nieves. La solidaridad como pedagogía. Buenos Aires: Ciudad Nueva, 2000.

Titlebaum, Peter, Gabrielle Williamson, Corinne Daprano, Janine Baer, Jayne Brahler. Annotated History of Service Learning 1862-2002. Dayton, OH: University of Dayton, May 2004.

UKM, National University of Malaysia. Strengthening Community Engagement. Nurturing Caring Citizens. Kuala Lumpur: UKM, 2012. 